Article

\title{
Influence of Hemlock Woolly Adelgid Infestation Levels on Water Stress in Eastern Hemlocks within the Great Smoky Mountains National Park, U.S.A.
}

\author{
Carla Coots ${ }^{1, *}$, Paris Lambdin ${ }^{1}$, Jennifer Franklin ${ }^{2}$, Jerome Grant ${ }^{1}$ and Rusty Rhea ${ }^{3}$ \\ 1 Department of Entomology and Plant Pathology, The University of Tennessee, Knoxville, \\ TN 37996, USA; E-Mails: plambdin@utk.edu (P.L.); jgrant@utk.edu (J.G.) \\ 2 Department of Forestry, Wildlife and Fisheries, The University of Tennessee, Knoxville, \\ TN 37996, USA; E-Mail: jafranklin@utk.edu \\ 3 USDA Forest Service, Forest Health Protection, 200 Weaver Boulevard, Asheville, NC 28804, \\ USA; E-Mail: rrhea@fs.fed.us
}

* Author to whom correspondence should be addressed; E-Mail: cdillin1@utk.edu; Tel.: +1-865-974-4979; Fax: +1-865-974-4744.

Academic Editors: Jarmo K. Holopainen and Eric J. Jokela

Received: 13 August 2014 / Accepted: 3 December 2014 / Published: 20 January 2015

\begin{abstract}
Extensive mortality of eastern hemlock, Tsuga canadensis (L.) Carrière, resulting from infestation by hemlock woolly adelgid, Adelges tsugae Annand (Hemiptera: Adelgidae), has occurred throughout the eastern United States. Although imidacloprid treatment can reduce tree mortality, its effectiveness can be influenced by several factors including tree water stress. The relationship between water stress and infestation rates is unknown, and an understanding of these could greatly increase the efficiency of management for this invasive insect. The primary objective of this study was to assess water stress at three levels of hemlock woolly adelgid infestations. Water stress was measured monthly for 13 months in eastern hemlocks classified as $<25 \%, 25 \%-75 \%$, and $>75 \%$ infested. The highest level of water stress was found in those trees with hemlock woolly adelgid infestation levels greater than $75 \%$. The lowest level of water stress was found in those trees with less than $25 \%$ hemlock woolly adelgid infestation levels. Knowledge of these effects can contribute to development of more effective chemical management strategies.
\end{abstract}


Keywords: Adelges tsugae; Tsuga canadensis; water stress; infestation levels; southern appalachians

\section{Introduction}

Large scale mortality of eastern hemlock, Tsuga canadensis (L.) Carrière, resulting from infestation by hemlock woolly adelgid, Adelges tsugae Annand (Hemiptera: Adelgidae), has occurred throughout the eastern United States over the past decade. Imidacloprid, a systemic insecticide, is one of the primary chemicals used to suppress populations of hemlock woolly adelgid [1]. Although imidacloprid treatment can reduce tree mortality, its effectiveness is influenced by several factors, including tree water stress [2]. Adelgid infestation has recently been found to influence tree water relations in mature stands [2] and saplings [3] but this relationship between water stress and infestation rates is basically unknown, and an understanding of these could greatly increase the efficiency of management for this invasive insect. Two species of hemlock, eastern hemlock, Tsuga canadensis (L.) Carrière, and Carolina hemlock, Tsuga caroliniana Engelmann, are found in the eastern United States. Eastern hemlock is a shade-tolerant, slow growing and drought intolerant conifer species [4] found on nearly eight million hectares of forest in the eastern United States. It is formerly considered to be the dominant tree on about one million of those hectares [4] and comprises approximately 1528 hectares in the Great Smoky Mountains National Park. Its geographic range extends from Nova Scotia south to northern Georgia and west to Minnesota. Carolina hemlock is considered a rare relic species limited in range to the Blue Ridge Mountains in the Southern Appalachians.

Eastern hemlock is a foundational species constituting a vital component of biological diversity, environmental homeostasis, and economic substantiality within its geographic range [5-9]. Eastern hemlock is a vital foliage resource for deer in the winter [10], is correlated to avian community composition [11], and is associated with more than 400 species of insects [6,12]. Eastern hemlocks also serve as a key component of riparian habitats, lowering stream temperature, stabilizing diel variation in stream temperature, regulating stream flow, and producing an aquatic environment favorable to fish and aquatic macroinvertebrates [9]. Eastern hemlocks fulfill unique ecological roles that contribute to environmental stability. Deep shade and slowly decomposing acidic litter result in a distinct microclimate characterized by temperature reduction, moisture retention, lowered rates of nitrogen cycling, and nutrient poor soils [13].

The hemlock woolly adelgid has proven to be detrimental to both eastern hemlock and Carolina hemlock in eastern North America since its introduction in Richmond, Virginia in 1951. It now ranges as far north as Massachusetts, south to North Carolina and north Georgia, and west into Tennessee and Kentucky. Hemlock mortality is caused by reduced carbohydrate reserves in the tree as result of adelgid feeding in the ray parenchyma cells [14] and reduced photosynthetic rates [15-17], affecting trees of all size and age classes [18]. Damage to the tree from heavy adelgid infestation reduces the ability of the hemlock to transport imidacloprid, one of the primary systemic chemicals used to treat infestations of hemlock woolly adelgid, throughout the tree [1,13]. Hemlock woolly adelgid infestations cause 
abnormal wood production in the xylem [17] similar to that which is documented in Frasier fir with balsam woolly adelgid [19].

Eastern hemlocks under drought stress and those with needle loss and dieback have difficulty transporting systemic insecticides into the canopy [20]. This difficulty may be the result of low transpiration rates of stressed leaves, which limits the uptake and movement of water. Reduction of adelgid populations as the result of imidacloprid treatment has been shown to dramatically increase new growth, resulting in the recovery of trees that had been in poor condition, although the rate of recovery is highly dependent on the health of the tree at the beginning of treatment as well as the degree of water stress [20]. Translocation of imidacloprid has been shown to occur in eastern hemlock throughout the entire canopy, and has been shown to persist for more than two years [20]; however, trees in that study were under minimal drought stress and low infestation levels of hemlock woolly adelgid prior to treatment. Little is known regarding how water stress is related to differing hemlock woolly adelgid infestation levels. Knowledge of this relationship is critical for targeting treatments to trees in which they will be most beneficial, and making effective treatment decisions to protect this important resource. The primary objective of this study is to assess the correlation between hemlock woolly adelgid infestation level and water stress in eastern hemlock.

\section{Materials and Methods}

\subsection{Study Site and Experimental Design}

The study was conducted at three sites within the Great Smoky Mountains National Park (Tennessee). The experiment was arranged in a single factor $(<25 \%, 25 \%-75 \%$, and $>75 \%$ hemlock woolly adelgid infestation ratings) randomized complete block design with three sites, using air temperature, rainfall, relative humidity, soil temperature, and soil moisture as covariates. Sites were established at $327 \mathrm{~m}$ $(1075 \mathrm{ft})$ at Shop Creek $\left(35^{\circ} 31^{\prime} 56^{\prime \prime} \mathrm{N}, 83^{\circ} 56^{\prime} 31^{\prime \prime} \mathrm{W}\right)$, at $792 \mathrm{~m}(2600 \mathrm{ft})$ in Cosby $\left(35^{\circ} 46^{\prime} 40^{\prime \prime} \mathrm{N}\right.$, $\left.83^{\circ} 28^{\prime} 41^{\prime \prime} \mathrm{W}\right)$, and at $1490 \mathrm{~m}$ (4889 ft) on Sugarland Mountain (35 36 $\left.34^{\prime \prime} \mathrm{N}, 8^{\circ} 28^{\prime} 41^{\prime \prime} \mathrm{W}\right)$. Eastern hemlocks at Shop Creek were located in a valley cove with $<25 \%$ slope, in upland sandy loam soil. Eastern hemlocks located at Cosby were located in a valley cove with $<35 \%$ slope, in loamy sand soil. Eastern hemlocks at the Sugarland Mountain site were located on ridge with $<45 \%$ slope, in upland sandy loam soil. Eastern hemlocks selected $(n=27)$ were of similar height $(12-15 \mathrm{~m})$ and diameter at breast height $(\mathrm{DBH})(25-38 \mathrm{~cm})$ to reduce error due to the effects these factors have on water uptake in eastern hemlock. Of these trees selected, nine were established within each site and arranged in groups of three, with each group of trees representing one of the three infestation rating categories with each infestation rating category represented. Infestation ratings were determined by cutting $15(40 \mathrm{~cm})$ branches from each tree using a pole pruner. Five branch samples were taken from the lower strata, 5 from the mid strata, and 5 from the upper strata. The living sisten generation of adelgids from the terminal $25 \mathrm{~cm}$ of the branches were counted up to 20 , with 20 representing 100 percent infestation rating [21].

\subsection{Sampling and Measurements}

Water stress was determined as a measurement of stem water potential $(\Psi)$, using a portable pressure chamber (Model 615, PMS Instrument Company, Albany, OR, USA). The higher the degree of water 
stress the more negative the water potential. Four $12 \mathrm{~cm}$ branches were cut from the apical end of the branch on each tree, two from the bottom and two from the top of the canopy. A pole pruner was used to acquire branch samples from the top stratum of the tree. Measurements from foliage were taken once each month for 13 months (August 2011-August 2012), resulting in a total of 1404 branch samples. Measurements were made mid-day between the hours of $11 \mathrm{am}-3 \mathrm{pm}$, when plant moisture stress was at its maximum. The extensive elevation range of eastern hemlock in the southern Appalachians results in varying site characteristics, which may influence water stress in the tree. Site characteristics were monitored using HOBO's (Model 10164748 and U23-001, Onset Computer Company (Bourne, MA, USA) with two HOBO's placed within each block of trees $5 \mathrm{~m}$ above ground, and soil sensors (Model 10171749, Onset Computer Company) to monitor soil temperature and moisture placed around the base of trees at a depth of $36 \mathrm{~cm}$. HOBO's were used to record daily ambient air temperature $\left({ }^{\circ} \mathrm{C}\right)$, rainfall $(\mathrm{cm} / \mathrm{h})$, relative humidity $(\%)$, soil temperature $\left({ }^{\circ} \mathrm{C}\right)$, and soil moisture $(\%$ volume $)$.

\subsection{Data Analysis}

Data were subjected to verification of the assumptions of normality and homoscedasticity. Daily ambient air temperature $\left({ }^{\circ} \mathrm{C}\right)$, rainfall $(\mathrm{cm} / \mathrm{h})$, relative humidity $(\%)$, soil temperature $\left({ }^{\circ} \mathrm{C}\right)$, and soil moisture (\% volume) measurements were treated as covariates. Least squares regression was used to determine the relationship between water stress and covariates. Because least squares means involve multiple statistical comparisons, a Bonferroni corrected $\alpha$ was used to avoid type I errors. Repeated measure analysis of covariance (ANCOVA) was conducted to assess for significant regression relationships among water stress and covariates through time, adjusting data for the effects of covariates using SAS statistical software [22]. Infestation level is the fixed factor, block is the random factor, and time is the repeated measures factor. ANCOVA adjusted means were separated using Student-Newman-Keuls post-hoc test $(\alpha=0.05)$ for differences in water stress across three hemlock woolly adelgid infestation levels within each month sampled.

\section{Results and Discussion}

A significant relationship was found among all covariates (daily ambient air temperature, rainfall, relative humidity, soil temperature, and soil moisture $)(F=2.25, \mathrm{df}=14,42, p<0.0001)$. This significant relationship indicates that these environmental factors were all related to levels of water stress in eastern hemlocks. Changes in environmental factors result in variations in microclimate that interact with site characteristics. These variations may partially explain disparities in water stress and systemic insecticide movement between geographic locations (local, regional, and national), and is an area that warrants more research.

Water stress in eastern hemlocks was significantly different (Student-Newman-Keuls test; $p<0.05$ ) between varying levels of hemlock woolly adelgid infestation (Figure 1). Eastern hemlocks with high infestation levels $(>75 \%)$ had significantly higher water stress (Student-Newman-Keuls test; $p<0.05$ ) than those trees with moderate level infestations $(25 \%-75 \%)$ and low level infestations $(<25 \%)$ (Figure 1). Eastern hemlocks with low level infestations had the lowest water stress out of all infestation levels (Figure 1). Temporal differences in water stress were documented across all hemlock woolly adelgid infestation levels (Figure 2). Water stress was significantly highest (Student-Newman-Keuls 
Test; $p<0.05$ ) across all infestation levels in April, which coincides with documented peak transpiration of eastern hemlock in the southern Appalachians in the spring [2]. As water stress increases, embolism occurs in the xylem which reduces hydraulic conductivity, eventually leading to catastrophic xylem failure. In eastern hemlock, the greatest rate of embolism was recorded between $-3 \mathrm{MPa}$ and $-5 \mathrm{MPa}$ [23]. We found stem water potentials of infested trees to be within this range for much of the year. Because woody plants commonly function near the level of catastrophic xylem failure [24], when soils are dry, the difference of $-0.5 \mathrm{MPa}$ between the least and most infested classes of trees may mean that trees at the highest level of infestation are approaching or crossing a critical threshold. However the lower water potential we observed in infested trees may also be the result of osmotic adjustment as the tree acclimates; large increases in proline, commonly used for osmotic adjustment, have been found in infested trees [25].

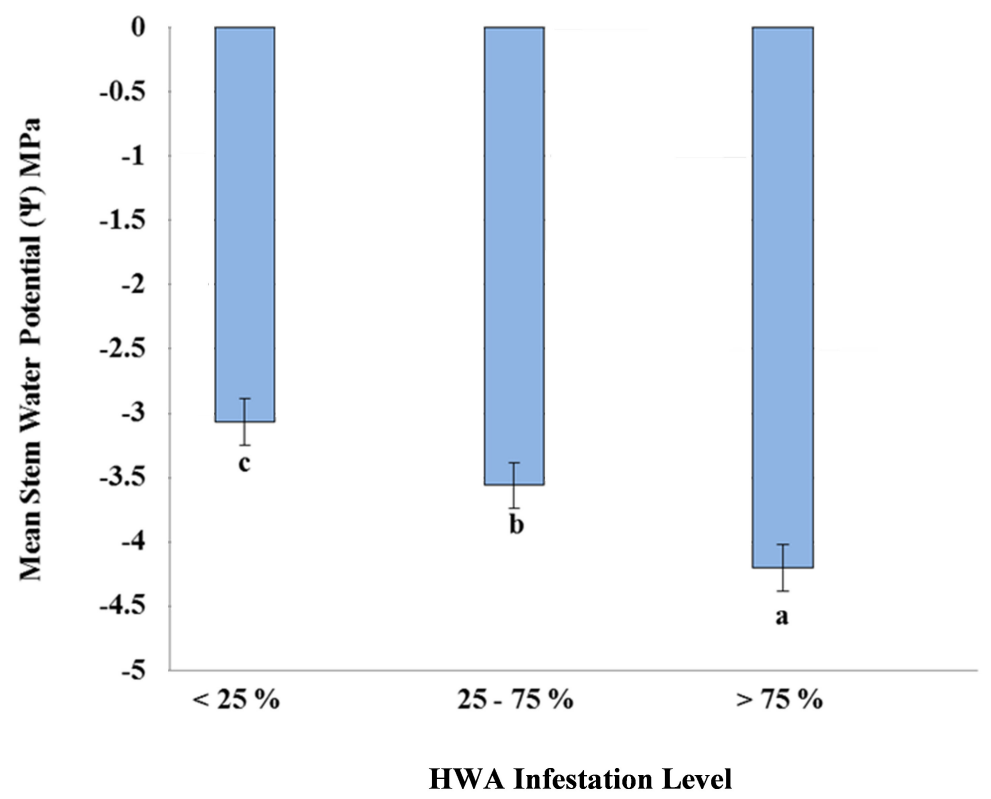

Figure 1. Relationship between Hemlock Woolly Adelgid (HWA) infestation level and stem water potential $(\Psi)$ as an indicator of water stress. Adjusted means $(n=1404)( \pm \mathrm{SE})$ with different letters are significantly different (Student-Newman-Keuls Test; $p<0.05$ ). The more negative the stem water potential $(\Psi)$, the more water stress is occurring in the tree.

April was when the highest average monthly rainfall $(10.12 \mathrm{~cm})$ and the highest average monthly soil moisture $(37.3 \%)$ were recorded, and there began a slow recovery of water potential toward the same levels in August, as were seen the previous year. Significant differences (Student-Newman-Keuls Test; $p<0.05$ ) documented between infestation levels indicate that higher hemlock woolly adelgid infestation levels werestrongly related to levels of water stress within the tree. The lowest water stress occurred across all infestation levels in January, which coincided with reduced transpiration rates of eastern hemlock in the southern Appalachians [2]. The lowest average monthly rainfall was documented in January $(8.02 \mathrm{~cm})$, suggesting that transpiration rates rather than precipitation patterns were the primary driver of seasonal water potential fluctuations in this species. Even under favorable conditions, the reduction in water potential we observed to occur with increasing infestation may have resulted in a 
higher incidence of mid-day stomatal closure and reductions in photosynthesis, as has been previously observed in this species [15].

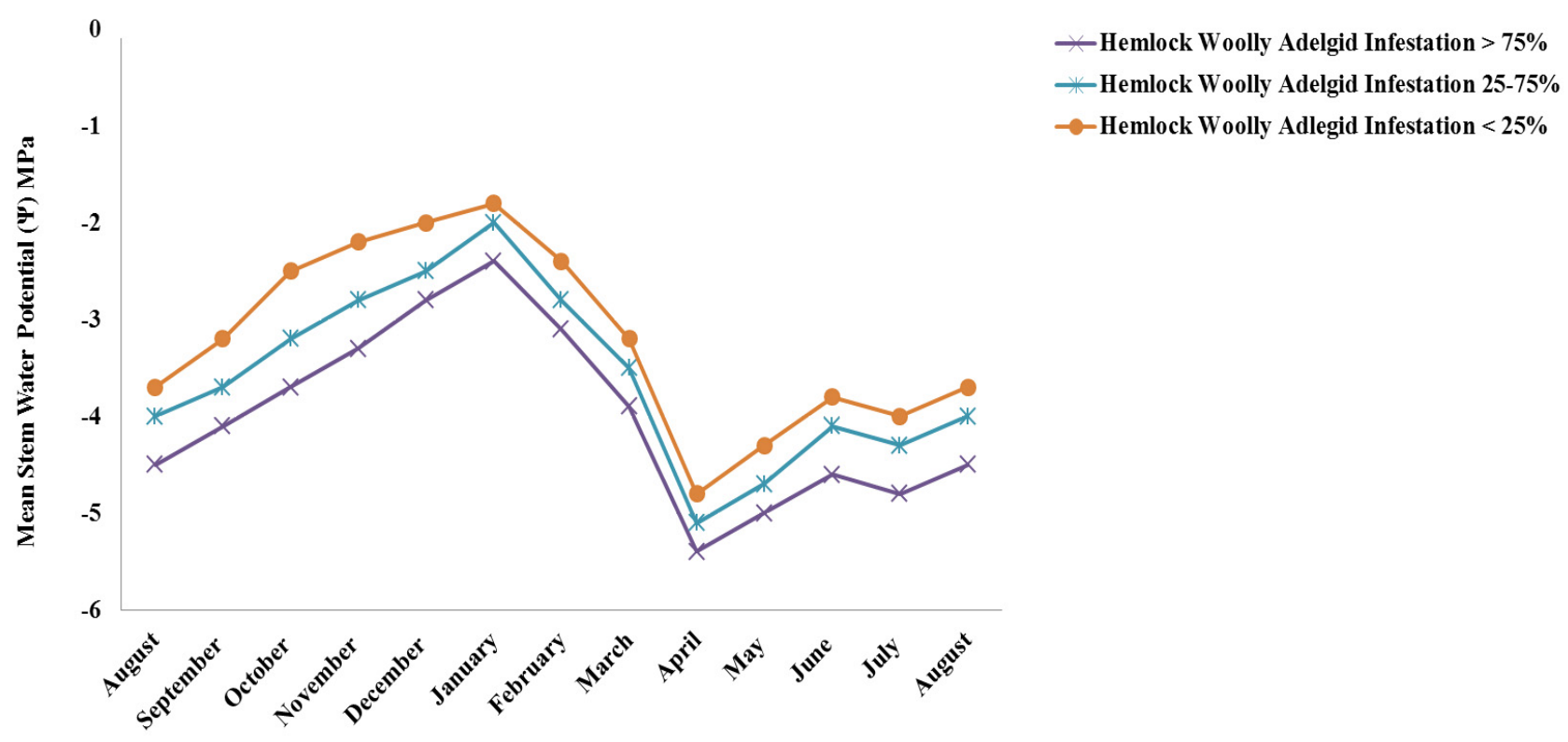

Figure 2. Temporal variation of adjusted water stress as a function of adjusted mean stem water potential ( $\Psi$ ) as an indicator of water stress from August 2011 to August 2012. The more negative the stem water potential $(\Psi)$, the more water stress is occurring in the tree. Mean stem water potential $(\Psi)$ was significantly different between all infestation levels within each month (Student-Newman-Keuls Test; $p<0.05$ ).

Accelerated mortality in eastern hemlocks is likely to occur at high hemlock woolly adelgid infestation levels. Along with transpiration rate, two natural forces govern the movement of water in plants: (1) the mechanics of cohesion theory and (2) an osmotic gradient from the soil to the root, however, interruptions in these forces can cause water stress in a tree resulting in detrimental effects to growth, photosynthesis, and transpiration. Hemlock woolly adelgid infestations may influence water movement within eastern hemlocks by causing the formation of abnormal xylem structures, resulting in greater number of annual rings, increased amounts of ray tissue, and a reduction in the number of conducting pit pores and encrusted membranes [25]. Research by Domec et al. 2013 [15] found that constraints on water movement were correlated with abnormal wood production in the xylem of infested trees, resulting in greater water stress within the tree. Infested trees have also been found to have reduced fine root biomass [26] and mid-day transpiration rates [15]. These characteristics are conducive to limiting the movements of water within eastern hemlocks [17]. Conclusions from studies of Fraser fir, Abies fraseri (Pursch) Poir (Pinales: Pinaceae), with balsam woolly adelgid, Adelges piceae Ratzeburg (Hempitera: Adelgidae) [19], suggest that infestation may directly influence water conduction within the tree resulting in increased susceptibility to environmental stress and external symptoms of water stress.

Integrating the relationship between hemlock woolly adelgid infestation levels and environmental factors may contribute to developing models to predict water stress in eastern hemlocks. The prediction of water stress can help land managers and owners develop management strategies that can prioritize hemlock stands in areas where systemic insecticide treatments would be most beneficial. 


\section{Conclusions}

The results from this study indicate a strong relationship between hemlock woolly adelgid infestations and water stress. Eastern hemlock trees with hemlock woolly adelgid infestations greater than $75 \%$ had the highest water stress, tress with infestations between $25 \%$ and $75 \%$ had moderate water stress, and trees with $<25 \%$ infestation had significantly lower water stress. Temporal differences in water stress indicate that highest water stress in eastern hemlocks occurs in April. Environmental factors, such as ambient air temperature, rainfall, relative humidity, soil temperature, and soil moisture can vary between sites and are also related to levels of water-stress. Knowledge of these effects can contribute to more effective chemical management strategies of hemlock woolly adelgid by understanding the implications these factors have in the movement of systemic insecticides within the tree as a result of high or relatively lower water stress.

\section{Acknowledgments}

We thank D. Paulsen (Department of Entomology and Plant Pathology, University of Tennessee, Knoxville, TN, USA) for assistance with field experiments, the USDA Forest Service and the Great Smoky Mountain Conservation Association for their financial support of this project.

\section{Author Contributions}

Carla Coots contributed to study design, study execution, and manuscript preparation. Paris Lambdin, Jennifer Franklin, Jerome Grant and Rusty Rhea contributed to study design and manuscript preparation.

\section{Conflicts of Interest}

The authors declare no conflict of interest.

\section{References}

1. Cowles, R. Optimizing dosage and preventing leaching of imidaclorpid for management of Hemlock Woolly Adelgid in forests. For. Ecol. Manag. 2009, 257, 1026-1033.

2. Ford, C.R.; Vose, J.M. Tsuga canadensis (L.) Carr. mortality will impact hydrological processes in the southern Appalachian forest ecosystems. Ecol. Appl. 2007, 17, 1156-1167.

3. Gonda-King, L.; Gómez, S.; Martin, J.L.; Orians, C.M.; Preisser, E. Tree responses to an invasive sap-feeding insect. Plant Ecol. 2014, 215, 297-304.

4. Ward, J.S. Restoration of damaged stands: Dealing with the after effects of hemlock woolly adelgid. In Proceedings of the Hemlock Woolly Adelgid in the Eastern United States Symposium, East Brunswick, NJ, USA, 5-7 February 2002; Onken, B., Reardon, R., Lashomb, J., Eds.; Rutgers University: New Brunswick, NJ, USA, 2002; pp. 118-126.

5. Schmidt, T.L.; McWilliams, W.H. Status of eastern hemlock in the northern U.S. In Proceedings of the Regional Conference on Ecology and Management of Eastern Hemlock, Iron Mountain, MI, USA, 27-28 September 1995; Mroz, G., Martin, J., Eds.; University of Wisconsin: Madison, WI, USA, 1996; pp. 61-72. 
6. Buck, S.; Lambdin, P.; Paulsen, D.; Grant, J.; Saxton, A. Checklist of insect species associated with eastern hemlock in the Great Smoky Mountains National Park and environs. Tenn. Acad. Sci. 2005, $80,1-10$.

7. Kelty, M.J. Productivity of New England hemlock/hardwood stands as affected by species composition and canopy structure. For. Ecol. Manag. 1989, 28, 237-257.

8. DeGraaf, R.M.; Yamasaki, M.; Leak, W.B.; Lanier, J.W. New England Wildlife: Management of Forested Habitats; Gen. Tech. Rep. NE-144; USA Department of Agriculture, Forest Service, Northeastern Forest Experiment Station: Radnor, PA, USA, 1992; p. 15.

9. Snyder, C.; Young, J.; Smith, D.; Lemarie, D.; Ross, R.; Bennett, R. Stream Ecology Linked to Eastern Hemlock Decline in Delaware Water Gap National Recreation Area; USA Geological Survey: Kearneysville, WV, USA, 2004. Available online: http:/www.lsc.usgs.gov/aeb/ 2048-03/dewa.asp (accessed on 1 December 2014).

10. Lapin, B. The Impact of Hemlock Woolly Adelgid on Resources in the Lower Connecticut River Valley; Dept. of Agriculture, Forest Service, Northeastern Center for Forest Health Research: Hamden, CT, USA, 1994; p. 10.

11. Tingley, M.W.; Orwig, D.; Field, R.; Motzkin, G. Avian response to removal of a forest dominant: consequences of hemlock woolly adelgid infestations. J. Biogeogr. 2002, 29, 1505-1516.

12. Dilling, C.I.; Lambdin, P.L.; Grant, J.F.; Buck, S.L. Insect guild structure associated with eastern hemlock in the southern Appalachians. Environ. Entomol. 2007, 36, 1408-1414.

13. Evans, R.A. An ecosystem unraveling? In Proceedings of the Hemlock Woolly Adelgid in the Eastern United States Symposium, East Brunswick, NJ, USA, 5-7 February 2002; Onken, B., Reardon, R., Lashomb, J., Eds.; Rutgers University: New Brunswick, NJ, USA, 2002; pp. 254-268.

14. Young, R.F.; Shields, K.S.; Berlyn, G.P. Hemlock woolly adelgid (Homoptera: Adelgidae): Stylet bundle insertion and feeding sites. Ann. Entomol. Soc. Am. 1995, 88, 827-835.

15. Domec, J.-C.; Rivera, L.N.; King, J.S.; Peszlen, I.; Hain, F.; Smith, B.; Frampton, J. Hemlock woolly adelgid (Adelges tsugae) infestation affects water and carbon relations of eastern hemlock (Tsuga canadensis) and Carolina hemlock (Tsuga caroliniana). New Phytol. 2013, 199, 452-463.

16. Jenkins, J.; Aber, J.D.; Canham, C.D. Hemlock woolly adelgid impacts on community structure and $\mathrm{N}$ cycling rates in eastern hemlock forests. Can. J. For. Res. 1999, 29, 630-645.

17. Nelson, L.A.; Dillaway, D.N.; Rieske, L.K. Effect of an exotic herbivore, Adelges tsugae, on photosynthesis of a highly susceptible Tsuga host, with notes on conspecifics. Arthropod Plant Interact. 2014, 8, 9-15.

18. McClure, M.S. Biological Control of Hemlock Woolly Adelgid in the Eastern United States; FHTET 2000-08; The USDA Forest Service, Forest Health Technology Enterprise Team: Morgantown, WV, USA, 2001; p. 10.

19. Arthur, F.H.; Hain, F.P. Seasonal history of the balsam woolly adelgid (Homoptera: Adelgidae) in natural stands and plantations of Frasier fir. Econ. Entomol. 1985, 77, 1154-1158.

20. Dilling, C.I.; Lambdin, P.L.; Grant, J.F.; Rhea, J.R. Spatial and temporal distribution of imidacloprid in eastern hemlock in the southern Appalachians. Econ. Entomol. 2010, 103, 368-373.

21. Cowles, R.S.; Montgomery, M.E.; Cheah, C.A.S.-J. Activity and residues of imidacloprid applied to soil and tree trunks to control hemlock woolly adelgid (Hemiptera: Adelgidae) in forests. Econ. Entomol. 2006, 99, 1258-1267. 
22. SAS Institute Inc. SAS User's Guide, Statistics; SAS Institute Inc.: Cary, NC, USA, 2006.

23. Tyree, M.T.; Sperry, J.S. Vulnerability of xylem to cavitation and embolism. Ann. Rev. Plant Physiol. Plant Mol. Biol. 1989, 40, 19-36.

24. Tyree, M.T.; Sperry, J.S. Do woody plants operate near the point of catastrophic xylem dysfunction caused by dynamic water stress? Answers from a model. Plant Phys. 1988, 88, 574-580.

25. Gómez, S.; Orians, C.; Preisser, E. Exotic herbivores on a shared native host: Tissue quality after individual, simultaneous, and sequential attack. Oecologia 2012, 169, 1015-1024.

26. Nuckolls, A.E.; Wurzburger, N.; Ford, C.R.; Hendrick, R.L.; Vose, J.M.; Kloeppel, B.D. Hemlock declines rapidly with hemlock woolly adelgid infestation: Impacts on the carbon cycle of southern Appalachian forests. Ecosystems 2009, 12, 179-190.

(C) 2015 by the authors; licensee MDPI, Basel, Switzerland. This article is an open access article distributed under the terms and conditions of the Creative Commons Attribution license (http://creativecommons.org/licenses/by/4.0/). 